\title{
Genotip 1b Kronik Hepatit C Hastalarında Kalıcı Virolojik Yanıtın Değerlendirilmesi
}

\author{
Evaluation of Sustained Virological Response in Patients with Genotype $1 \mathrm{~b}$ \\ Chronic Hepatitis C Infection
}

\author{
Esragül AKINCI, Bircan ÜNAL KAYAASLAN, Aliye TANRICI BAŞBUĞ, Selim Sırrı EREN, \\ Pınar ÖNGÜRÜ, Hürrem BODUR \\ Ankara Numune Eğitim ve Araştırma Hastanesi, Enfeksiyon Hastalıkları ve Klinik Mikrobiyoloji Kliniği, Ankara, Türkiye
}

\section{ÖZET}

Amaç: Kliniğimizde 2003-2010 yılları arasında takip ve tedavisi yapılan sirozu olmayan 50 erişkin genotip $1 \mathrm{~b}$ kronik hepatit C $(\mathrm{KHC})$ hastasında kalıı virolojik yanıt oranlarının değerlendirilmesi amaçlandı.

Gereç ve Yöntemler: Hasta verileri retrospektif olarak değerlendirildi. HBV veya HIV ko-enfeksiyonu, otoimmün hepatiti, sirozu ve gebeliği olan hastalar calışma dışında bırakıldı.

Bulgular: Hastaların \%54'ü erkek, ortalama yaş 44,6 $6 \pm 11,2$ (19-65), ortalama ALT değeri 57 $\pm 38,7$ (8-239) IU/L ve ortalama HCV RNA düzeyi 8x105 $\pm 2,6 \times 106$ (579-1,6x107) IU/ml idi. Vakaların \%94'ü daha önceden hiç tedavi almamış naiv hasta iken, \%6'sında önceki tedaviden sonra relaps gelişmişti. Karaciğer biyopsi sonuçlarına göre ortalama histolojik aktivite indeksi 6,2 23,1 , ortalama

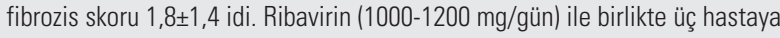
standart IFN- $\alpha, 47$ hastaya pegile IFN- $\alpha$ kombinasyonu başlandı. Yan etki nedeniyle \%42 hastada ilaç doz ayarı yapıldı. Ciddi psikiyatrik sorunlar, şiddetli halsizlik ve aşıı kilo kaybı gelişen 8 hastada tedavi 48 haftaya tamamlanamadan kesildi. Hızı virolojik yanıt (HVY) \%64, erken virolojik yanıt (EVY) \%84, kalıcı virolojik yanıt (KVY) \%68 oranında tespit edildi. Tedaviye yanıtsılık oranı $\% 12$ iken tedaviye yanıt alınan hastaların \%23'ünde relaps gelişti. Tek değişkenli analizde genç hastalarda, HVY ve EVY alınanlarda KVY oranı daha yüksekti $(p<0,05)$. Yan etkiler nedeniyle ilaç dozu azaltılanlarda ve tedaviyi erken kesmek zorunda kalanlarda ise KVY oranı düşüktü $(p<0,05)$. Çok değişkenli analizde, KVY'ı gösteren tek bağımsız değişken HVY idi. HVY alınan hastaların \%96,3'ünde KVY elde edildi.

Sonuç: Non-sirotik, tedavi uyumu yüksek, düşük fibrozis skoru olan seçilmiş hasta grubunda genotip-1 kronik hepatit B tedavisinde daha yüksek oranlarda KVY elde edilebilmektedir. (Viral Hepatit Dergisi 2013; 19(2): 80-4)

Anahtar Kelimeler: Hepatit C, kalıc yanıt, interferon, ribavirin

\section{ABSTRACT}

Objective: We aimed to evaluate 50 adult non-cirrhotic patients with genotype $1 \mathrm{~b}$ chronic hepatitis C (CHC) whose followed in our clinic between 2003-2010.

Materials and Methods: Data of the patients were evaluated retrospectively. HBV or HIV co-infections, otoimmune hepatitis, sirotic patients and pregnants were excluded from the study.

Results: Of the patients $54 \%$ were male, mean age was $44.6 \pm 11.2$ (19-65), mean ALT was $57 \pm 38.7 \mathrm{IU} / \mathrm{L}(8-239)$ and mean HCV RNA was $8 \times 105 \pm 2.6 \times 106 \mathrm{IU} / \mathrm{ml}$ (5791.6x107). Among them $94 \%$ were naive and $6 \%$ were relapsers. Mean HAl was $6.2 \pm 3.1$ and mean fibrosis score was 1.8 \pm 1.4 . Three patients were given standard interferon- $\alpha$ and 47 were given pegylated interferon- $\alpha$ in combination with ribavirin (1000-1200 mg/day). Dose adjustment was done in $42 \%$ of the patients due to side effects. Duration of therapy was shorter than 48 weeks in eight patients due to severe psychiatric side effects, excessive weight loss and weakness. Rapid virological response (RVR) was achieved in 64\%, early virological response (EVR) in $84 \%$ and sustained virological response (SVR) in $68 \%$ patients. Among the patients $12 \%$ were non-responders and $23 \%$ of the responders were relapsed after the therapy. In univariate analysis, younger age, RVR, EVR, dose reduction and short duration of the treatment were predictors of SVR ( $p<0.05)$. RVR was the only independent predictor of SVR in multivariate analysis. SVR was developed in $96.3 \%$ of the patients with RVR.

Conclusion: As a result, higher SVR rates can be obtained in non-cirrhotic patients whose have low fibrosis score and high treatment compliance. (Viral Hepatitis Journal 2013; 19(2): 80-4)

Key words: Hepatitis C, sustained virological response, interferon, ribavirin

Yazıșma Adresi/Address for Correspondence: Dr. Esragül Akıncı, Ankara Numune Eğitim ve Araștırma Hastanesi, Enfeksiyon Hastalıkları ve Klinik Mikrobiyoloji Kliniği, Altındağ, Ankara, Türkiye Tel.: +90 3125084841 E-mail: esragulakinci@gmail.com Geliş tarihi/Received: 27.01.2013 Kabul tarihi/Accepted: 24.06.2013 


\section{Giriş}

Hepatit C virüsü (HCV) kronik karaciğer hastalığının önemli etkenlerinden biridir. Dünyada 200 milyonu aşkın kişide kronik hepatit $\mathrm{C}(\mathrm{KHC})$ enfeksiyonu mevcuttur. Bu da dünya nüfusunun yaklaşık \%3'ünü oluşturur $(1,2)$. Hastalığın prevalansı coğrafik bölgeler arasında farklılıklar gösterir. Batı Avrupa'da düşük oranlarda görülürken Doğu Avrupa ve Orta Doğu'da oranlar daha yüksektir (3).

Çoğunlukla asemptomatik seyreden akut HCV enfeksiyonu \%50-90 oranında kronikleşir. Kronik HCV enfeksiyonu tedavi edilmediğinde \%10-40 oranında siroza ilerler ve bunların da yılda \%1-5'inde hepatosellüler karsinom (HCC) gelişir $(4,5)$. KHC tedavisinde primer amaç kanda dolaşan virüsü elimine ederek kalıcı iyileşmeyi sağlamak ve böylece siroz, HCC gibi komplikasyonların oluşmasını önlemektir. Kalıcı virolojik yanıt alınması, sirozu olmayan hastalarda karaciğerdeki kalıcı iyileşmeyi göstermektedir (6). Bu çalışmada kliniğimizde tedavi edilen hastalar arasından, verilen tedavi protokolüne uyum gösteren ve tedavi bittikten sonra en az 1 yıl takipleri yapılan non-sirotik genotip 1b KHC olgularının değerlendirilmesi amaçlanmıştır.

\section{Gereç ve Yöntem}

Kliniğimizde 2003-2010 yılları arasında KHC tanısı alan 73 hasta arasından tedavi boyunca takipten çıkmayan, verilen tedavi protokolünü uygulayan ve tedavi bittikten sonra en az bir yıl kontrolleri yapılan non-sirotik 50 erişkin genotip 1b KHC hastası çalışmaya alındı. KHC tanısı, en az 6 aydır bilinen serum Anti-HCV pozitifliği olan hastalarda RT-PCR ile HCV RNA'nın pozitif bulunması ve/veya karaciğer biyopsisinde kronik hepatit ile uyumlu bulguların saptanması ile konuldu. HBV veya HIV ko-enfeksiyonu, otoimmün hepatiti, sirozu ve gebeliği olan hastalar çalışma dışında bırakıldı. Çalışma hasta takip formları kullanılarak retrospektif olarak yapıldı.

Üç hastaya standart interferon- $\alpha$ (sIFN- $\alpha$ ) haftada 3 kez 3 MU sc + ribavirin kombinasyonu, diğer hastalara pegile interferon- $\alpha$ (PEG IFN- $\alpha$ ) haftada 1 kez sc + ribavirin kombinasyonu başlandı. Ribavirin, $75 \mathrm{~kg}$ altındaki hastalara $1000 \mathrm{mg} / \mathrm{gün}, 75 \mathrm{~kg}$ üstündeki hastalara 1200 mg/gün dozunda verildi. Tedaviye başlamadan önce karaciğer ve böbrek fonksiyon testleri, tam kan sayımı, troid fonksiyon testleri, otoantikorlar, HBsAg, Anti-HBs, Anti-Delta, AntiHIV, AntiHAV total ve hemostaz testlerine bakıldı. Tedavi başlandıktan sonra 4, 12, 24 ve 48. haftalarda HCV RNA düzeyleri görüldü. HCV RNA değerinin 4. haftada negatifleşmesi hızlı virolojik yanıt (HVY), 12. haftada negatifleşmesi erken virolojik yanıt (EVY), 48. hafta sonunda devam eden HCV RNA negatifliği tedavi sonu yanıt (TSY) olarak değerlendirildi. Tedavinin 12. haftasında HCV RNA değerinde 2 log veya üzerinde düşüş olmayan ya da 24. haftada HCV RNA değeri negatifleşmeyen olgular yanıtsız kabul edilerek tedavileri kesildi. Tedavisi tamamlanan hastaların 3, 6 ve 12 ay sonra HCV RNA kontrolleri yapıldı. TSY alınan hastalarda tedavi bittikten 6 ay sonraki HCV RNA negatifliği kalıcı virolojik yanıt (KVY) olarak değerlendirildi. HCV RNA'nın tekrar pozitifleşmesi durumunda ise relaps düşünüldü. KVY elde edilen hastalarda yılda bir kez HCV RNA kontrolü yapıldı ve devam eden HCV RNA negatifliği uzun dönem kalıcı virolojik yanıt (UKVY) olarak kabul edildi. McHutchinson ve arkadaşlarının geliştirdiği 80/80/80 kuralına göre ( $\geq \% 80$ pegIFN dozu, $\geq \% 80$ ribavirin dozu, $\geq \% 80$ tedavi süresi) hastalar değerlendirilerek tedavi dozu ve süresine uyum analiz edildi (7).

Hastaların aylık kontrolleri yapıldı. Kontrollerde yan etkiler sorgulanarak tam kan sayımı ve kan biyokimyasına bakıldı. Tetkiklerinde anormal değerler saptanan hastalar daha sık kontrollere çağrıldı. Üç ayda bir tiroid fonksiyon testleri (TFT) istendi. Tiroidit ortaya çıkanlarda ise ayda bir TFT görüldü. Yan etki gelişen (nötrofil $<750 / \mathrm{mm} 3$, trombosit $<50,000 / \mathrm{mm} 3$ ya da hemoglobin $<10 \mathrm{~g} / \mathrm{dL}$ ) hastalarda ilaç doz ayarı yapıldı.

Verilerin istatistiksel analizinde SPSS 16 istatistik programı (IL, USA) kullanıldı. Tek değişkenli ve çok değişkenli analizler yapılarak kalıcı virolojik yanıt alınan hasta verileri ile yanıt alınamayan ya da relaps gelişen hasta verileri karşılaştırıldı. Analizlerde $p<0,05$ değeri anlamlı kabul edildi.

\section{Bulgular}

Hastaların 27'si (\%54) erkek, 23'ü (\%46) kadın idi. Ortalama

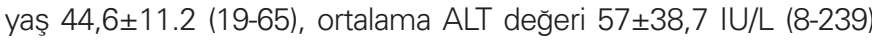

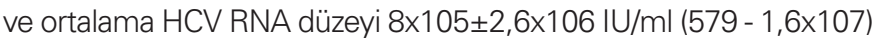
olarak bulundu. Vakaların 47'si (\%94) daha önceden hiç tedavi almamış naiv hasta iken, 3 (\%6) hastada önceki tedaviden sonra relaps gelişmişti. Karaciğer biyopsisi 33 hastaya yapılabildi. Biyopsi sonuçlarına göre ortalama histolojik aktivite indeksi $6,2 \pm 3,1$, ortalama fibrozis skoru 1,8 1,4 idi.

Üç hastaya sIFN- $\alpha+$ ribavirin, 17 hastaya PEG IFN- $\alpha$ 2a + ribavirin, 30 hastaya da PEG IFN- $\alpha 2 b$ + ribavirin başlandı. Yan etki nedeniyle 21 (\%42) hastada (anemi 8, nötropeni 4, trombositopeni 1, hemolitik anemi 3, aşırı bulantı ve kusma 3, şiddetli halsizlik ve aşırı kilo kaybı 1, kontrol edilemeyen anksiyete 1 hasta) ilaç doz ayarı yapıldı. Ciddi psikiyatrik sorunlar (intihar düşüncesi, psikotik atak), şiddetli halsizlik ve aşırı kilo kaybı gelişen 8 (\%16) hastada ise tedavi 48 haftaya tamamlanamadan kesildi. Bu hastaların 6'sı 24 hafta, 2'si 36 hafta tedavi aldı. Hastaların \%74'ünde 80/80/80 kuralı sağlandı.

Çalışmaya alınan hastalarda HVY \%64 (27/42), EVY \%84 (42/50), TSY \%88 (44/50), KVY \%68 (34/50) oranında elde edildi (Tablo 1). KVY alınan hastalar $57,2 \pm 31,6$ ay (12-112) takip edildi. Takiplerde tümünde HCV-RNA negatif bulundu ve UDKVY olarak değerlendirildi. Altı hasta (\%12) tedaviye yanıtsız iken TSY alınan 44 hastanın 10'unda (\%23) relaps gelişti. Tedavi sonrası kontrollerde iki hastada 1. ayda, beş hastada 3. ayda, bir hastada 6. ayda, 2 hastada 7. ayda relaps tespit edildi. Daha önceden tedavi almış ve relaps gelişmiş dört hastaya ikinci kez tedavi verildi. Bu hastaların üçünde ilk tedavide Peg-IFN- $\alpha$ 2b, birinde Peg-IFN- $\alpha$ 2a kullanılmıştı. Hastaların ikisinde 2. kez tedavide KVY sağlanırken birinde 2 . tedaviye de yanıt alınamadı. Bir hasta ise şiddetli halsizlik ve aşırı kilo kaybı nedeni ile tedaviyi devam ettiremedi.

Tek değişkenli analizde genç hastalarda, HVY ve EVY alınanlarda KVY oranı anlamlı derecede yüksekti $(p<0,05)$ (Tablo 2). Yan etki nedeniyle ilaç dozu azaltılanlarda ve tedaviyi erken kesmek zorunda kalanlarda ise KVY oranı anlamlı oranda düşüktü $(p<0,05)$. Yüksek viral yük, karaciğer biyopsi skorları ve tedavide kullanılan interferon tiplerinin KVY'ı etkilemediği görüldü. Çok değişkenli analizde, KVY elde edileceğini gösteren tek bağımsı değişken HVY idi. HVY alınan hastaların \%96,3'ünde KVY elde edildi. Tedaviye bağlı yan etkiler arasında en sık görülen klinik semptomlar ateş, miyalji ve iştahsızık; en sık saptanan laboratuvar bulgular ise lökopeni ve anemi idi (Tablo 3). 


\begin{tabular}{|lll|}
\hline Tablo 1. Hastaların özellikleri ve tedavi yanıtı & & \\
\hline & $\mathbf{n}$ & $\%$ \\
\hline Hastaların Özellikleri & & \\
Erkek cinsiyet & 27 & 54 \\
Naive & 47 & 94 \\
Relaps & 3 & 6 \\
Yüksek ALT (> 35 IU/L) & 30 & 60 \\
Yüksek HCV RNA (> 600 000 IU/mI) & 33 & 66 \\
\hline Interferon Tipi & & \\
Peg-IFN 2b & 30 & 60 \\
Peg-IFN 2a & 17 & 34 \\
Standart interferon & 3 & 6 \\
\hline Ribavirin Dozu & & \\
1000 mg/gün & 35 & 70 \\
1200 mg/gün & 15 & 30 \\
\hline Tedavi Yanıtı & & \\
Hızlı virolojik yanıt* & & \\
Erken virolojik yanıt & 27 & 64 \\
Tedavi sonu yanıt & 42 & 84 \\
Kalıcı virolojik yanıt & 44 & 88 \\
Yanıtsız & 34 & 68 \\
Relaps** & 6 & 12 \\
\hline
\end{tabular}

\section{Tartışma}

KHC tedavisinde primer amaç KVY elde etmektir. KVY'a ulaşma oranı genotip 1 hastalar için \%40-50, genotip 2 ve 3 hastalar için \% 70-80 arasında değişen oranlarda bildirilmiştir (8-10). Ülkemizde KHC hastalarında genotip $1 \mathrm{~b}$ en slk tespit edilen $(\% 81,7-96,5)$ HCV genotipidir (11-12). Ülkemiz verilerine göre KHC tedavisi alan hastalarda KVY oranı \%41,2 ile \%64,4 arasında değişmektedir (15-20). Bizim çalışmamızda KVY \%68 oranında elde edilmiştir. Hastaların tedaviye uyumu yüksek olan gruptan seçilmiş olması, sirotik hastaların çalışmaya alınmaması ve karaciğer fibrozis skorlarının düşük olmasının bu sonuç üzerinde etkili olabileceği düşünülmüştür (21). Çalışmamızda \%12 hastada tedaviye yanıt alınamamıştır. Ülkemizde yapılan diğer çalışmalarda da PEG IFN + ribavirin alan hastalarda tedaviye yanıtsılık oranları benzer şekilde \%10,5-19,3 arasında değişen oranlarda saptanmıştır $(15,17)$.

KHC'de tedavi başarısı pek çok faktörle ilişkili bulunmuştur. KVY'ı etkileyen en güçlü faktörler HCV genotipi, fibrozis evresi ve genotip-1 hastalarda 19 nolu kromozomdaki gen polimorfizmi (IL28B) olarak rapor edilmiştir (10). Tedavi cevabını etkileyen diğer faktörler ise bazal HCV-RNA düzeyi, tedavi dozu ve süresi, vücut kitle indeksi, insülin direnci, yaş ve ko-enfeksiyonlardır. Bu çalışmada KVY ile HVY, EVY, yaş, doz ayarı ve tedavi süresi arasında anlamlı bir ilişki bulunurken viral yük, HAl ve fibrozis evresi ile KVY arasında anlamlı bir ilişki saptanmamışıı. Nonsirotik olguların seçilmesi, hastaların çoğunda fibrozis skorunun düşük ve birbirine yakın olması gibi faktörlerin bu sonucu etkilemiş olabileceği düşünülmüştür. Çalışmada HVY elde edilen hastaların hemen tümünde KVY'a ulaşıımıs ve KVY'ı tahmin etmede en kuvvetli göstergenin HVY olduğu tespit edilmiştir. Benzer şekilde başka bir çalışmada da HVY

Tablo 2. Kalıcı virolojik yanıtı etkileyen faktörler

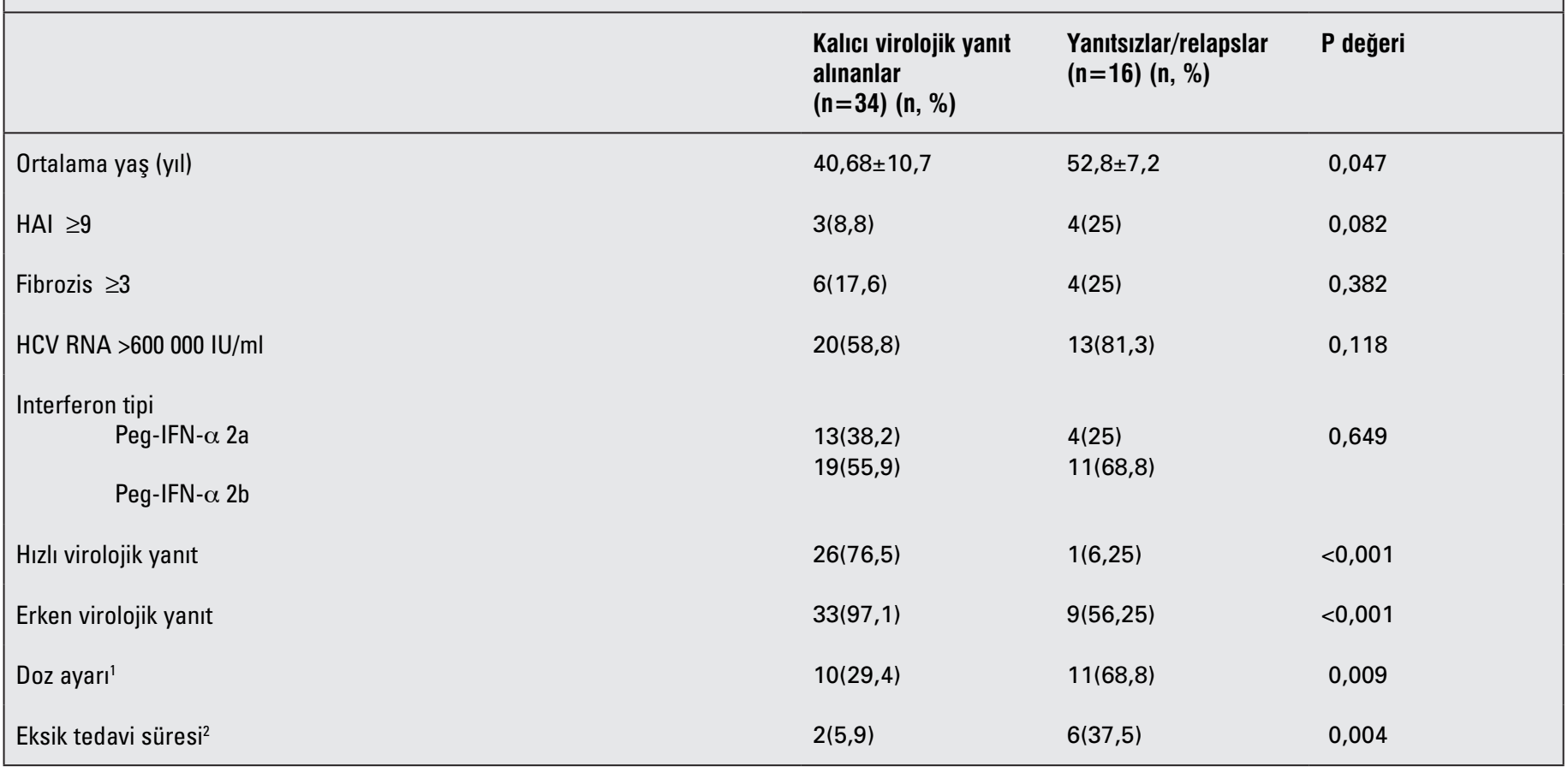


alınan tüm hastalarda KVY elde edilmiştir (18). Çeşitli çalışmalarda KVY'ı etkileyen farklı faktörler bulunmuştur. Bir çalışmaya göre kadın cinsiyet, düşük viral yük, EVY ve genotip 2 KVY oranını artıırken yaş, vücut kitle indeksi, HAl, fibrozis ve verilen interferon tipi KVY'ı etkilememektedir (17). Başka bir çalışmada ileri yaş, yüksek viral yük, düşük trombosit sayısı, yüksek HAl inflamasyon skoru ve yüksek fibrozis KVY'ı olumsuz etkileyen faktörler olarak saptanmıştır (19). Diğer bir çalışmaya göre ise yüksek viral yük ( $\geq 2 \times 106$ kopya/mL) virolojik relapsların en önemli belirleyicisidir (22).

$\mathrm{KHC}$ tedavisinde elde edilen $\mathrm{KVY}^{\prime} ı n$ karaciğerden virüsün eradike edildiğini gösterdiği ileri sürülmektedir. Bir çok çalışmada KVY alınan hastaların uzun dönem takiplerinde (2-3 yıl) nüks görülmediği, nükslerin tedaviden sonraki ilk 6 ayda ortaya çıktığı bildirilmektedir $(17,22-25)$. Hatta karaciğer dokusunda ve periferal kan hücrelerinde HCV RNA'nın araştırıldığı bir çalışmada 18 yıl sonra bile KVY'ın devam ettiği gösterilmiştir (26). Bununla birlikte başka bir araştırmada relaps süresinin 54 aya kadar uzayabileceği (tedavi sonrası 1-54 ay, ortalama 6,6 ay), 6. aydan sonra relaps görülme oranının \%11,8 olduğu rapor edilmiştir (27). Genel literatür bilgisiyle uyumlu olarak bizim çalışmamızda da tedavi sonrası uzun dönem takiplerde tüm hastalarda KVY devam etmiş, kontrolüne gecikmeli gelen 2 hasta dışında (7 ay) relapslar tedavi bittikten sonraki 6 ay içinde görülmüştür.

\begin{tabular}{|c|c|c|}
\hline Yan Etkiler & $\mathbf{n}$ & $\%$ \\
\hline \multicolumn{3}{|l|}{ Genel } \\
\hline Miyalji/halsizlik & 35 & 70 \\
\hline İştahsızlık & 35 & 70 \\
\hline Ateş & 30 & 60 \\
\hline Kilo kaybı & 28 & 56 \\
\hline Bulantı/kusma & 10 & 20 \\
\hline \multicolumn{3}{|l|}{ Hematolojik } \\
\hline Lökopeni & 37 & 74 \\
\hline Anemi & 31 & 62 \\
\hline Trombositopeni & 15 & 30 \\
\hline \multicolumn{3}{|l|}{ Psikiyatrik } \\
\hline Uykusuzluk & 8 & 16 \\
\hline Anksiyete & 6 & 12 \\
\hline Depresyon/psikotik atak & 4 & 8 \\
\hline Konsantrasyon bozukluğu & 4 & 8 \\
\hline \multicolumn{3}{|l|}{ Diğer } \\
\hline Döküntü & 7 & 14 \\
\hline Troidit & 6 & 12 \\
\hline Saç dökülmesi & 5 & 10 \\
\hline Kaşıntı & 4 & 8 \\
\hline KOAH alevlenme & 3 & 6 \\
\hline LAP & 2 & 4 \\
\hline Psöriyazis & 1 & 2 \\
\hline
\end{tabular}

KHC tedavisinde kullanılan interferon ve ribavirin ciddi yan etkileri olan ilaçlardır. Yan etkiler nedeniyle tedavinin optimal doz ve sürede uygulanamaması tedavi cevabını negatif yönde etkilemektedir $(17,18,28)$. Çalışmada ciddi hematolojik yan etkiler nedeniyle bazı hastalarda doz azaltımı yapılmış, bazı hastalarda ise ciddi psikiyatrik problemler, aşırı halsizlik ve kilo kaybı sonucu tedavi tamamlanamadan kesilmiştir. Her iki durum da KVY'ı olumsuz etkilemiştir.

Sonuç olarak, literatürde genotip 1 KHC enfeksiyonlarının tedavi başarısı diğer genotiplere göre çok daha düşük oranlarda bildirilmesine rağmen, non-sirotik, tedavi uyumu yüksek, düşük fibrozis skoru olan seçilmiş hasta grubunda daha yüksek oranlarda KVY elde edilebilmektedir. Ancak bu çalışmadaki vaka sayısı azdır. Daha sağlıklı sonuçların elde edilmesi için fazla sayıda hasta ile yapılan çok merkezli çalışmalara intiyaç vardır.

\section{Çıkar Çatışması: Bildirilmemiştir.}

\section{Kaynaklar}

1. Lavanchy D. The global burden of hepatitis C. Liver Int. 2009; 29(Suppl): 74-81.

2. Shepard CW, Finelli L, Alter MJ. Global epidemiology of hepatitis C virus infection. Lancet Infect Dis. 2005; 5(9): 558-67

3. Esteban JI, Sauleda S, Quer J. The changing epidemiology of hepatitis C virus infection in Europe. J Hepatol. 2008; 48(1): 148-62.

4. Afdhal NH. The natural history of hepatitis C. Semin Liver Dis 2004; 24(Suppl 2): 3-8.

5. Thompson CJ, Rogers G, Hewson P, Wright D, Anderson R, Cramp M, et al. Surveillance of cirrhosis for hepatocellular carcinoma: systematic review and economic analysis. Health Technol Assess. 2007; 11: 1-206.

6. Ghany MG, Strader DB, Thomas DL, Seeff LB. Diagnosis, management, and treatment of hepatitis $\mathrm{C}$ : an update. Hepatology. 2009; 49: 1335-74.

7. McHutchison JG, Manns M, Patel K, Poynard T, Lindsay KL, Trepo C, et al. Adherence to combination therapy enhances sustained response in genotype-1-infected patients with chronic hepatitis C. Gastroenterology 2002; 123: 1061-69.

8. Fried MW, Shiffman ML, Reddy KR, Smith C, Marinos G, Goncales FL, et al. Peginterferon alfa-2a plus ribavirin for chronic hepatitis C virus infection. New Engl J Med. 2002; 347: 975-82.

9. Hadziyannis SJ, Sette H, Morgan TR, Balan V, Diago M, Marcellin $\mathrm{P}$, et al. Peginterferon-alpha $2 \mathrm{a}$ and ribavirin combination therapy in chronic hepatitis $\mathrm{C}-\mathrm{a}$ randomized study of treatment duration and ribavirin dose. Ann Intern Med. 2004; 140: 346-55.

10. Manns MP, Wedemeyer $H$, Cornberg M. Treating viral hepatitis C: efficacy, side effects, and complications. Gut. 2006; 55(9): 1350-59

11. Gökahmetoğlu S, Bozdayı M, Ozbakır O, et al. Hepatitis C virus genotypes detected in Erciyes University. J Turk Mikrobiol Society. 2007; 37: 35-8.

12. Altuglu I, Söyler I, Özacar T, Erensoy S. Distribution of hepatitis $C$ virus genotypes in patients with chronic hepatitis $C$ infection in Western Turkey. Int J Infect Dis. 2008; 12(3): 239-44.

13. Küçüköztaş $M F$, Özgüneş $N$, Yazıcı $S$. Investigation of the relationship between Hepatitis $\mathrm{C}$ virus (HCV) genotypes with HCV RNA and alanine aminotransferase levels in chronic hepatitis C patients. Mikrobiyol Bul 2010; 44(1): 111-15.

14. Selcuk H, Kanbay M, Korkmaz $M$ et al. Distribution of HCV genotypes in patients with end-stage renal disease according to type of dialysis treatment. Dig Dis Sci. 2006; 51(8): 1420-25. 
15. Sünbül M, Kuruoğlu T, Horoz IH, Esen Ș, Eroğlu C, Leblebicioğlu $\mathrm{H}$. Kronik hepatit $\mathrm{C}$ tedavisi alan hastalarda uzun dönem kalıcı virolojik yanıt oranları. Viral Hepatit Dergisi 2008; 13: 7-11.

16. Özgür G, Şener B, Ünal E. Kronik hepatit C tedavi yanıtlarının değerlendirilmesi. XI. Ulusal Viral Hepatit Kongresi, 12-15 Nisan 2012, Antalya. Kongre Kitabı: s173.

17. Koruk ST, Koruk I, Çalışır C, Karsen H. The follow-up results with sustained virologic response in chronic hepatitis $C$ patients in Şanlıurfa/Turkey. J microbial Infect Dis. 2012; 2: 14-20

18. Bilgül $M$, Sibel $Y$, Özaras $R$ ve ark. Kronik hepatit $C$ tanılı hastaların tedavi yanıtlarının değerlendirilmesi: Cerrahpaşa deneyimi. XI. Ulusal Viral Hepatit Kongresi, 12-15 Nisan 2012, Antalya. Kongre Kitabı: s192.

19. Özden K, Özkurt Z, Erol S, Parlak M. Peg-IFN ve ribavirin tedavisi alan kronik hepatit $C$ hastalarında kalıcı viral yanıtı etkileyen faktörler. XI. Ulusal Viral Hepatit Kongresi, 12-15 Nisan 2012, Antalya. Kongre Kitabı: s191

20. Sümer Ş, Ural O, Demir NA, Ural G, Balcı M, Dikici N. Kronik hepatit C'li hastalarda standart interferon alfa $2 \mathrm{a}+$ ribavirin kombinasyonu ile pegileinterferon alfa $2 a$ + ribavirin kombinasyonunun etkinliğinin karşılaştırılması. Viral Hepatit Dergisi. 2009; 14: 87-90.

21. Zeuzem S. Heterogeneous virologic response rates to interferonbased therapy in patients with chronic hepatitis $\mathrm{C}$ who respond less well? Ann Intern Med. 2004;140(5):370-81.

22. Ceylan B, Fincancı M, Müderrisoğlu C, Soysal F, Eren G. Tedaviye virolojik ve biyokimyasal yanıt veren kronik hepatit $C$ hastalarının uzun süreli takibi ve nüksü belirleyen değişkenlerin irdelenmesi. Viral Hepatit Dergisi. 2007; 12: 14-23.
23. Desmond CP, Roberts SK, Dudley F, et al. Sustained virological response rates and durability of the response to interferonbased therapies in hepatitis $C$ patients treated in the clinical setting. J Viral Hepat. 2006; 13(5): 311-15.

24. Ferreıra SC, Carneiro MV, Souza FF, et al. Long-term follow-up of patients with chronic hepatitis $\mathrm{C}$ with sustained virological response to interferon. Braz J Infect Dis. 2010; 14(4): 330-34.

25. Formann E, Steindl-Munda P, Hofer H, Jessner W, Bergholz $U$, Gurguta $C$, et al. Long-term follow-up of chronic hepatitis C patients with sustained virological response to various forms of interferon-based anti-viral therapy. Aliment Pharmacol Ther 2006; 23(4): 507-11.

26. Maylin S, Martinot-Peignoux M, Moucari R, et al. Eradication of hepatitis $\mathrm{C}$ virus in patients successfully treated for chronic hepatitis C. Gastroenterology. 2008; 135: 821-829.

27. Yardımcı AC, Fincancı M, Müderrisoğlu C, Bahadır C. Tedavi başarısı elde edilen kronik hepatit $\mathrm{C}$ hastalarında repals oranı ve relapsın ortaya çıkma zamanı. XI. Ulusal Viral Hepatit Kongresi, 12-15 Nisan 2012, Antalya. Kongre Kitabı: s177.

28. Özgüneş N, Semiha Ç, Saadet Y. 1994-2012 yılları arasında kliniğimizde takipli kronik viral hepatit $C$ hastalarından yan etki sebebiyle tedavisi kesilen hastaların değerlendirilmesi. XI. Ulusal Viral Hepatit Kongresi, 12-15 Nisan 2012, Antalya. Kongre Kitabı: s187. 